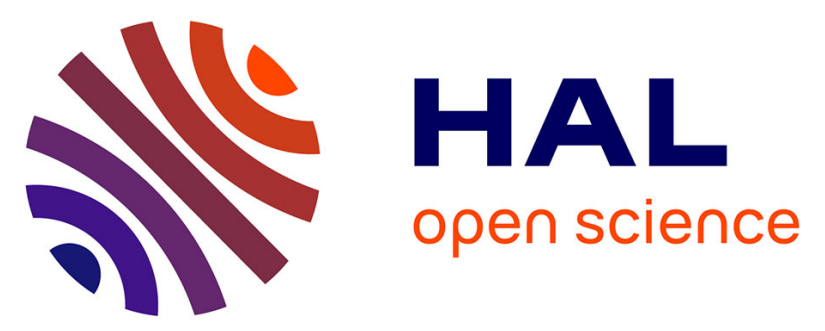

\title{
Reactive species output of a plasma jet with a shielding gas device - combination of FTIR absorption spectroscopy and gas phase modelling
}

A. Schmidt-Bleker, Joern Winter, S. Iseni, M. Dünnbier, K.-D. Weltmann, S. Reuter

\section{To cite this version:}

A. Schmidt-Bleker, Joern Winter, S. Iseni, M. Dünnbier, K.-D. Weltmann, et al.. Reactive species output of a plasma jet with a shielding gas device - combination of FTIR absorption spectroscopy and gas phase modelling. Journal of Physics D: Applied Physics, 2014, 47 (14), pp.145201. 10.1088/0022$3727 / 47 / 14 / 145201$. hal-02270235

\section{HAL Id: hal-02270235 \\ https://hal.science/hal-02270235}

Submitted on 28 Jun 2021

HAL is a multi-disciplinary open access archive for the deposit and dissemination of scientific research documents, whether they are published or not. The documents may come from teaching and research institutions in France or abroad, or from public or private research centers.
L'archive ouverte pluridisciplinaire HAL, est destinée au dépôt et à la diffusion de documents scientifiques de niveau recherche, publiés ou non, émanant des établissements d'enseignement et de recherche français ou étrangers, des laboratoires publics ou privés. 


\title{
Reactive species output of a plasma jet with a shielding gas device-combination of FTIR absorption spectroscopy and gas phase modelling
}

\author{
A Schmidt-Bleker ${ }^{1,2}, \mathbf{J}$ Winter $^{1,2}, \mathbf{S}$ Iseni ${ }^{1,2}, \mathbf{M}$ Dünnbier ${ }^{1,2}$, \\ K-D Weltmann ${ }^{2}$ and S Reuter ${ }^{1,2}$ \\ ${ }^{1}$ Centre for Innovation Competence plasmatis, 17489 Greifswald, Germany \\ ${ }^{2}$ Leibniz Institute for Plasma Science and Technology (INP), 17489 Greifswald, Germany \\ E-mail: Ansgar.Schmidt-Bleker@inp-greifswald.de
}

Received 20 December 2013, revised 6 February 2014

Accepted for publication 10 February 2014

Published 20 March 2014

\begin{abstract}
In this work, a simple modelling approach combined with absorption spectroscopy of long living species generated by a cold atmospheric plasma jet yields insight into relevant gas phase chemistry. The reactive species output of the plasma jet is controlled using a shielding gas device. The shielding gas is varied using mixtures of oxygen and nitrogen at various humidity levels. Through the combination of Fourier transform infrared (FTIR) spectroscopy, computational fluid dynamics (CFD) simulations and zero dimensional kinetic modelling of the gas phase chemistry, insight into the underlying reaction mechanisms is gained. While the FTIR measurements yield absolute densities of ozone and nitrogen dioxide in the far field of the jet, the kinetic simulations give additional information on reaction pathways. The simulation is fitted to the experimentally obtained data, using the CFD simulations of the experimental setup to estimate the correct evaluation time for the kinetic simulation. It is shown that the ozone production of the plasma jet continuously rises with the oxygen content in the shielding gas, while it significantly drops as humidity is increased. The production of nitrogen dioxide reaches its maximum at about $30 \%$ oxygen content in the shielding gas. The underlying mechanisms are discussed based on the simulation results.
\end{abstract}

Keywords: Fourier transform infrared spectroscopy, kinetic modelling, gas phase, plasma jet, fluid dynamics, neutral particles

\section{Introduction}

Cold atmospheric plasma (CAP) jets are gaining attention as a tool for biomedical applications, such as wound healing or cancer therapy [1-5]. Atmospheric pressure plasma sources generate a great variety of different reactive oxygen species (ROSs) and reactive nitrogen species (RNSs), which are relevant for their biological effects [6]. Plasma medicine research therefore faces the problem of disentangling the mechanisms involved in both the plasma and the biological samples or models. One approach enabling a distinction between biological effects based on ROSs and RNSs is the application of gas shielding devices, which can be used to generate a defined atmosphere, a shielding gas curtain, around the effluent of CAP jets $[7,8]$. The effect of different shielding gas compositions on nitrite, nitrate and hydrogen peroxide $\left(\mathrm{H}_{2} \mathrm{O}_{2}\right)$ concentrations in plasma treated liquids, on the viability of skin cells and on the cytotoxicity for skin and immune cells has been investigated $[7,9,10]$.

In order to understand the underlying mechanisms in plasma sources, zero dimensional (volume averaged) models involving hundreds to thousands of reactions [11-15] as well 
as space resolved simulations with reduced reaction sets have been successfully applied [16-19]. While space resolved models yield insight into fundamental physical aspects such as the streamer propagation $[17,18]$ or the interaction with biological tissue [16], zero dimensional models are useful for their fast computation time, which allows both large reaction sets and parametric studies. Sakiyama and Graves [15] have combined Fourier transform infrared (FTIR) spectroscopy and zero dimensional modelling for the investigation of the reactive species output of a dielectric barrier discharge. The direct combination of experimental techniques and simulations is particularly interesting, as it yields not only validated quantitative information on the species output, but also insight into the underlying chemical mechanisms. For the setup of the zero dimensional model presented in the following, the study of Van Gaens and Bogaerts [11] was especially valuable, as a similar argon operated plasma jet was investigated and main reaction pathways were discussed. The ozone production predicted therein was validated by UVabsorption measurements, yielding insight into its production and destruction mechanisms [20].

Quantitative measurements of several species on the plasma jet kinpen 09 (neoplas tools, Germany) used in this study have previously been made using spectroscopic methods such as laser induced fluorescence measurements [21, 22], infrared [23,24] and ultraviolet [22, 24, 25] absorption spectroscopy or mass spectrometry [26]. Depending on the species investigated, the studies were carried out using argon with molecular admixtures as feed gas: when atomic oxygen or ozone was measured oxygen was admixed with the feed gas $[21,24,25]$, for the measurement of $\mathrm{OH}$ water was admixed [22], and for $\mathrm{NO}_{2}$ air was admixed [23]. By using admixtures, the generation of the respective reactive species can be significantly increased. However, by adding molecular admixtures to the feed gas, not only one but presumably all reactive species generated by the jet are affected, as especially excited and ionized argon atoms and molecules are subject to significant quenching by molecular gases and the energy input and electron energy distribution in the core plasma zone inside of the jet is significantly altered. The theoretical description of the effects of feed gas admixture is therefore hard to achieve. In this work the kinpen 09 is operated with pure argon in combination with a shielding gas device. The shielding gas composition is varied from pure nitrogen to pure oxygen at different humidity levels. The goal of this approach is to leave the core plasma processes largely unaltered while the reactive species output is significantly regulated. The generation of reactive species is investigated by FTIR spectroscopy combined with computational fluid dynamics (CFD) simulations and zero dimensional kinetic modelling. FTIR spectroscopy yields the ozone $\left(\mathrm{O}_{3}\right)$ and nitrogen dioxide $\left(\mathrm{NO}_{2}\right)$ densities in the far field of the jet. In order to increase the absorption length in the FTIR measurements, a Whitetype multipass cell (MPC) is used. The time particles need to enter the MPC is determined by CFD simulations of the actual experimental setup. Through the combination of FTIR measurements and kinetic modelling, insight into the dynamics of reactive species upon shielding gas variations is gained.
The initial values of these simulations are fitted to the densities obtained from the FTIR measurements, while the evaluation time is determined from the CFD simulations. It is shown that not only can shielding gas variations be used as a tool for tailoring the reactive species output of a CAP jet, but also the variations of oxygen to nitrogen ratio and humidity level extend the experimental data set by two dimensions. This can be exploited to validate simulations and investigate reaction pathways.

As CAP sources are usually operated at ambient air and thus subject to varying ambient humidity, the influence of ambient humidity on some ROSs and RNSs relevant in the field of plasma medicine is discussed.

\section{Methods}

\subsection{Plasma jet and shielding gas device}

For the present study the cold atmospheric pressure plasma jet kinpen 09 is used. In the centre of a ceramics capillary a needle electrode driven at a frequency of $1.1 \mathrm{MHz}$ is mounted [27]. As feed gas argon (ALPHAGAZ 1, Air Liquide, France) with a gas flow rate of 3 standard liters per minute (slm) is applied.

In order to control the environment of the plasma jet, a shielding gas device is applied as presented in [7,8]. The shielding gas forms a curtain around the effluent of the plasma jet, shielding it from the ambient air and mixing the shielding gas into the reactive effluent. In the present work, different mixtures of oxygen and nitrogen (ALPHAGAZ 1, Air Liquide, France) with a constant total gas flow rate of $5 \mathrm{slm}$ are used as shielding gas. Furthermore, the humidity of the shielding gas can be adjusted using a bubbler setup in order to investigate the effect of ambient humidity on the generation of reactive species. In figure 1 the geometry of the plasma jet and the mole fraction of the shielding gas are depicted. The mole fraction is obtained by a CFD simulation using COMSOL 4.3 as discussed in [8]. Three regions are distinguished in figure 1: first, the core plasma zone inside of the plasma jet, where, apart from impurities, only argon is present; second, the effluent region, where mixing of the argon jet with the shielding gas occurs, and third, the far field, starting at a distance of about $12 \mathrm{~mm}$. While many reactive species may still be present in the far field, no visible emission takes place.

\subsection{FTIR absorption spectroscopy}

FTIR spectroscopy in the spectral range from 700 to $4000 \mathrm{~cm}^{-1}$ is used to both identify and quantify long living infrared active components produced by the argon plasma jet. As described above, the plasma jet is operated with dry argon as feed gas and mixtures of oxygen and nitrogen as shielding gas. The used experimental setup is schematically shown in figure 2 . The ratio of oxygen and nitrogen in the shielding gas is precisely adjusted by two mass flow controllers (labelled MFC; MKS Instruments, USA). By leading a part of this shielding gas flow through a water reservoir and combining it afterwards with the remaining dry shielding gas fraction, the shielding gas humidity can be varied in a very defined 


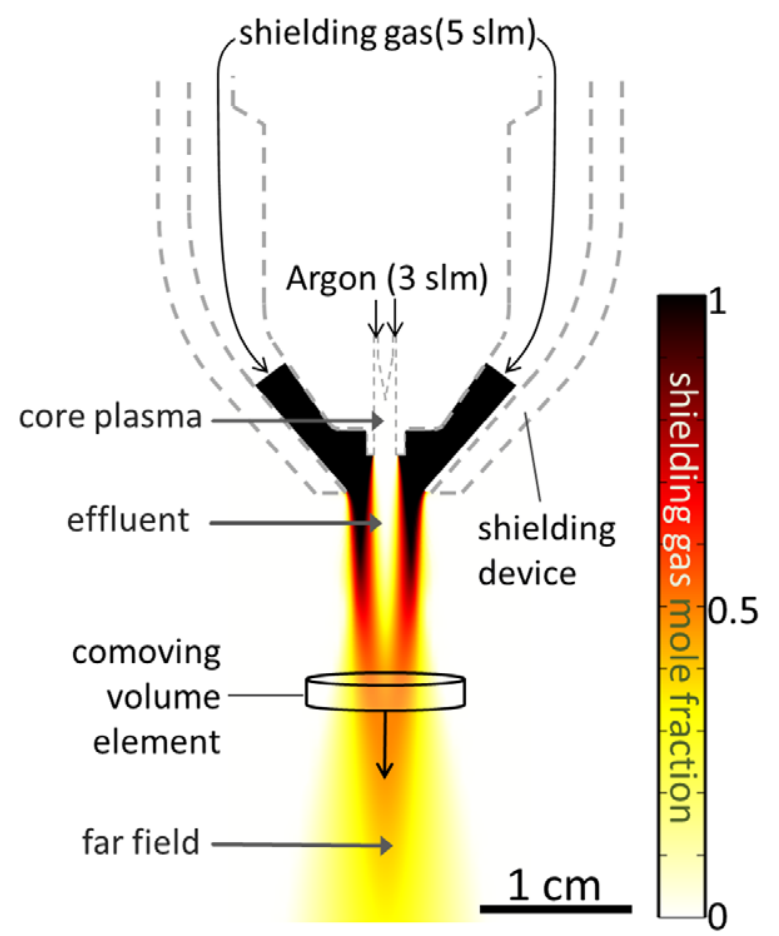

Figure 1. Sketch of the kinpen 09 geometry and visualization of the shielding gas curtain by CFD simulation. The zero dimensional reaction kinetics model can be interpreted as a volume average over a volume element comoving with the fluid (see section 2.3).

way. The humidity level was then measured by a hygrometer (DewMaster, EdgeTech, USA).

The jet and the shielding gas device are mounted on a cylindrical glass chamber with a diameter and length of $8 \mathrm{~cm}$ and $10 \mathrm{~cm}$, respectively. In this chamber plasma produced species interact with the artificially set ambient conditions before a fraction of the resulting composition is sucked into a evacuable multipass cell (Bruker, USA) with an absorption length of $19.2 \mathrm{~m}$. The pressure inside the multipass cell is monitored by a pressure gauge and set by an inlet and an outlet needle valve to 100 mbar. The gas flow rate from the mixing chamber into the multipass cell is $1.5 \mathrm{slm}$. The advantage of the lower pressure is the reduction of the particle collision rate, which results in a longer lifetime of the investigated species. Therefore, it is possible to detect species which tend to react and diminish quickly at ambient conditions. Additionally, the pressure broadening of the absorption signal is decreased, thus a differentiation of the measured signal and attribution to the respective molecules is easier to achieve. For the absorption measurements an FTIR spectrometer (Vertex 70v, Bruker, USA) was used.

In order to identify and quantify infrared active species from the measured absorption spectrum, a simulated spectrum is computed using spectroscopic data from the HITRAN database and the IR simulation software QMACSoft (neoplas control, Germany) [28,29] By means of the LevenbergMarquardt algorithm, the simulation is fitted to the measured absorption spectrum, yielding the species concentration [30].

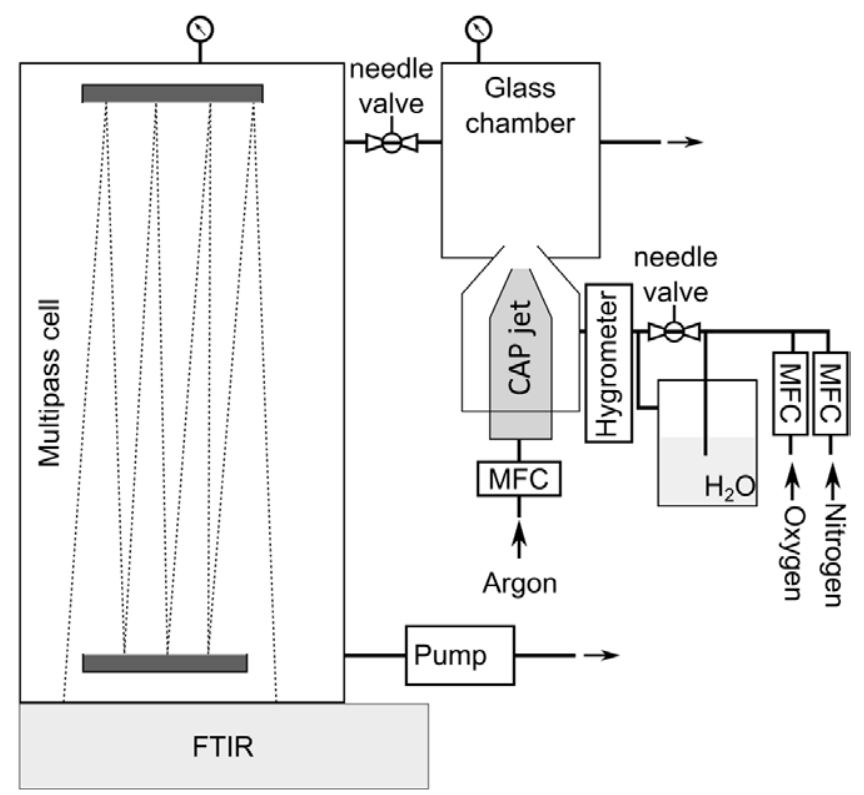

Figure 2. Schematic diagram of FTIR setup.

\subsection{Gas phase chemistry model}

In the core plasma of the CAP jet excited and ionized argon species are formed via electron impact reactions, e.g.

$$
\begin{aligned}
& \mathrm{e}+\mathrm{Ar} \rightarrow \mathrm{e}+\mathrm{Ar}^{*}, \\
& \mathrm{e}+\mathrm{Ar} \rightarrow 2 \mathrm{e}+\mathrm{Ar}^{+}
\end{aligned}
$$

In the following Ar* denotes the metastable 4s states of argon. As discussed in [11], it is very likely at atmospheric pressure that these argon species undergo three body collisions with an arbitrary collision partner $M$ forming the argon excimer and the molecular argon ion via the reactions

$$
\begin{aligned}
& \mathrm{Ar}^{*}+\mathrm{Ar}+M \rightarrow \mathrm{Ar}_{2}^{*}+M \\
& \mathrm{Ar}^{+}+\mathrm{Ar}+M \rightarrow \mathrm{Ar}_{2}^{+}+M
\end{aligned}
$$

The VUV emission from the argon excimer $\mathrm{Ar}_{2}^{*}$ has been detected in end-on measurements with the jet used in this study and was applied for the measurement of oxygen diffusion into the effluent of the jet [21]. In the effluent, electrons and reactive argon species may then dissociate, excite or ionize nitrogen, oxygen and water from the ambient, forming ROSs and RNSs. As discussed by van Gaens and Bogaerts [11], the most important loss reactions for the argon metastables and excimers are

$$
\begin{aligned}
& \mathrm{Ar}^{*}+\mathrm{O}_{2} \rightarrow \mathrm{Ar}+2 \mathrm{O}, \\
& \mathrm{Ar}^{*}+\mathrm{N}_{2} \rightarrow \mathrm{Ar}+2 \mathrm{~N}, \\
& \mathrm{Ar}^{*}+\mathrm{N}_{2} \rightarrow \mathrm{Ar}+\mathrm{N}_{2}^{*}, \\
& \mathrm{Ar}^{*}+\mathrm{Ar}_{2} \mathrm{O}=3.6 \times 10^{-11}, \\
& k_{\mathrm{Ar}}^{\mathrm{N}}=3.6 \times 10^{-11}, \\
& \mathrm{Ar}+\mathrm{OH}+\mathrm{H}, \quad k_{\mathrm{Ar}^{*}}^{\mathrm{OH}}=7.8 \times 10^{-10},
\end{aligned}
$$

while the argon excimers are mostly lost through

$$
\mathrm{Ar}_{2}^{*}+\mathrm{O}_{2} \rightarrow 2 \mathrm{Ar}+2 \mathrm{O}, \quad k_{\mathrm{Ar}_{2}^{*}}^{\mathrm{O}}=4.6 \times 10^{-11}
$$




$$
\begin{aligned}
& \mathrm{Ar}_{2}^{*}+\mathrm{N}_{2} \rightarrow 2 \mathrm{Ar}+\mathrm{N}_{2}^{*}, \quad k_{\mathrm{Ar}_{2}^{*}}^{\mathrm{N}_{2}^{*}}=1.2 \times 10^{-11}, \\
& \mathrm{Ar}_{2}^{*}+\mathrm{H}_{2} \mathrm{O} \rightarrow 2 \mathrm{Ar}+\mathrm{OH}+\mathrm{H}, \quad k_{\mathrm{Ar}_{2}^{*}}^{\mathrm{OH}}=7.8 \times 10^{-10}
\end{aligned}
$$

Here $k_{j}^{i}$ denote the rate constants for the reaction of the argon species $j$ yielding the excited or dissociated species $i$ from the respective air species. The rate constants were taken from [11], apart from the dissociation of water by $\mathrm{Ar}^{*}$, which is based on the studies presented in [31,32]. The rate for the dissociation of water to hydroxide $(\mathrm{OH})$ and hydrogen (11) is estimated based on (8). From the secondary species atomic oxygen, atomic nitrogen, nitrogen metastables $\left(\mathrm{N}_{2}^{*}\right.$ denotes the $\mathrm{N}_{2}(A)$ state) various ROSs and RNSs can be formed. Similarly, ions can be formed from air species via charge transfer from $\mathrm{Ar}^{+}$ and $\mathrm{Ar}_{2}^{+}$, Penning ionization or electronic processes. However, the quantity of the most abundant charged species is expected to be at least two orders of magnitude lower than those of the neutral species with highest abundance, as previous studies of argon operated atmospheric pressure plasma sources suggest [11,33-35].

The gas phase simulations presented in the present work are based on two assumptions:

(i) The initial concentrations of $\mathrm{O}, \mathrm{N}, \mathrm{N}_{2}^{*}, \mathrm{OH}$ and $\mathrm{H}$ mainly determine the dynamics of the most abundant ROSs and RNSs upon variation of the shielding gas composition.

(ii) The total amount of energy deposited in the plasma is independent of the shielding gas composition.

Assumption (i) is based on previous studies [11,33-35]. Excited oxygen states such as $\mathrm{O}_{2}\left({ }^{1} \Delta_{\mathrm{g}}\right)$ and $\mathrm{O}(1 \mathrm{D})$ (in the following denoted as $\mathrm{O}_{2}^{*}$ and $\mathrm{O}^{*}$ ) were not accounted for as discussed in section 3.2. Assumption (ii) is fulfilled by initializing each simulation, regardless of the shielding gas composition, with the same numbers of argon metastables and argon excimers. These argon species can then create $\mathrm{O}, \mathrm{N}$, $\mathrm{N}_{2}^{*}$, OH and $\mathrm{H}$ via reactions (5)-(11). While electrons also contribute to the generation of these species, they are not taken into account in the present simulation, as no information on the electron energy is available. This leaves the initial argon metastable and initial argon excimer density as free parameters, which can be used to fit the simulations to the FTIR measurements.

The simulations are carried out as follows. First, the branching ratios of the argon metastables and excimers are calculated based on reactions (5)-(11), yielding the initial densities for the secondary species $i, n_{i}$, as a function of the air species densities $n_{\mathrm{O}_{2}}, n_{\mathrm{N}_{2}}$ and $n_{\mathrm{H}_{2} \mathrm{O}}$ in the shielding gas and initial excited argon species densities $n_{\mathrm{Ar}^{*}}$ and $n_{\mathrm{Ar}_{2}^{*}}$ :

$$
\begin{gathered}
n_{\mathrm{O}}=2 n_{\mathrm{O}_{2}}\left(n_{\mathrm{Ar}^{*}} k_{\mathrm{Ar}^{*}}^{\mathrm{O}} \tau_{\mathrm{Ar}^{*}}+n_{\mathrm{Ar}_{2}^{*}} k_{\mathrm{Ar}_{2}^{*}}^{\mathrm{O}} \tau_{\mathrm{Ar}_{2}^{*}}\right) \\
n_{\mathrm{N}}=2 n_{\mathrm{N}_{2}}\left(n_{\mathrm{Ar}^{*}} k_{\mathrm{Ar}^{*}}^{\mathrm{N}} \tau_{\mathrm{Ar}^{*}}\right), \\
n_{\mathrm{N}_{2}^{*}}=n_{\mathrm{N}_{2}}\left(n_{\mathrm{Ar}^{*}} k_{\mathrm{Ar}^{*}}^{N_{2}^{*}} \tau_{\mathrm{Ar}^{*}}+n_{\mathrm{Ar}_{2}^{*}} k_{\mathrm{Ar}_{2}^{*}}^{\mathrm{N}_{2}^{*}} \tau_{\mathrm{Ar}_{2}^{*}}\right), \\
n_{\mathrm{OH} / \mathrm{H}}=n_{\mathrm{H}_{2} \mathrm{O}}\left(n_{\mathrm{Ar}^{*}} k_{\mathrm{Ar}^{*}}^{\mathrm{OH}} \tau_{\mathrm{Ar}^{*}}+n_{\mathrm{Ar}_{2}^{*}} k_{\mathrm{Ar}_{2}^{*}}^{\mathrm{OH}} \tau_{\mathrm{Ar}_{2}^{*}}\right) .
\end{gathered}
$$

Here $\tau_{\mathrm{Ar}^{*}}=\left(\sum_{i} n_{i} n_{\mathrm{Ar}^{*}} k_{\mathrm{Ar}^{*}}^{i}\right)^{-1}$ and $\tau_{\mathrm{Ar}_{2}^{*}}=\left(\sum_{i} n_{i} n_{\mathrm{Ar}_{2}^{*}} k_{\mathrm{Ar}_{2}^{*}}^{i}\right)^{-1}$ denote the lifetimes of the argon metastables and excimers due to the loss reactions (5)-(11). Two dimensional maps of the initial densities $n_{i}$ of the secondary species are plotted in figure 3 in dependence on the oxygen to nitrogen ratio and ambient humidity in the shielding gas. For the plots argon metastable and excimer densities of $n_{\mathrm{Ar}^{*}}=0.5 \times$ $10^{14} \mathrm{~cm}^{-3}$ and $n_{\mathrm{Ar}_{2}^{*}}=1 \times 10^{14} \mathrm{~cm}^{-3}$ were assumed, which are the values obtained from the fit of the simulations to the FTIR data on ozone and nitrogen dioxide as described in section 3.2. The kinetic simulations for the gas phase are then carried out solving the ordinary differential equations $\frac{\mathrm{d} n_{i}}{\mathrm{~d} t}=\sum$ generation $-\sum$ destruction for all species, where the generation and destruction processes for each species are the reactions (R1)-(R42) given in the appendix. Additional wall loss reactions in the glass chamber or the MPC are not considered, but are assumed to be negligible, as the surface to volume ratio is large. The number of reactions considered in the model is purposely kept minimal, as the model is intended as an advanced fitting routine rather than a self-consistent model. In this zero dimensional plug flow approach, time corresponds to the time of flight of a given volume element and is therefore equivalent to the distance $d=\int_{0}^{t} v(t) \mathrm{d} t$ of a volume element moving at a speed $v(t)$. The volume element can be thought of as a cylinder comoving with the fluid as depicted in figure 1, in which all species densities are spatially averaged. The correct time $t /$ distance $\mathrm{d}$ after which the model should be evaluated are discussed in the next section. Mixing of the shielding gas with the reactive argon jet is assumed to occur instantaneously, with the ambient species density rising to $\frac{5}{8} \times 2.49 \times 10^{19} \mathrm{~cm}^{-3}$, accounting for the composition in the mixing cell ( $5 \mathrm{slm}$ shielding gas plus $3 \mathrm{slm}$ argon). The abrupt increase of the ambient species density resembles the situation at the edge of the plasma jet nozzle. More detailed models should include the gradual diffusion of ambient species and the sub-microsecond excitation and dissociation process in the plasma jet. The current model is however designed to keep the number of free parameters minimal in order to function as a fitting routine.

\subsection{Estimation of timescales by CFD simulation}

In order to estimate the time of flight of a volume element that is transported from the plasma jet to the FTIR cell, a CFD simulation of the impulse response of the glass chamber was performed. That is, the mass flow of a tracer species through the inlet of the FTIR cell is computed when a short pulse of this tracer species at the inlet of the glass chamber is applied:

In a first step, the Navier-Stokes equations with the standard $k-\varepsilon$ model for turbulent flows were solved using COMSOL 4.3 , yielding the steady state velocity field $v$ within the cell and the turbulent diffusion coefficient $D=v / S c$. Here $v$ is the turbulent kinematic viscosity obtained from the $k-\varepsilon$ model, and for the turbulent Schmidt number the value $S c=0.7$ recommended for turbulent jet flows is used [36]. In a second step, the time dependent convection-diffusion equation $\partial_{t} c+\boldsymbol{v} \cdot \nabla c+\nabla \cdot(D \nabla) c=0$ for a tracer species $c$ is solved using 

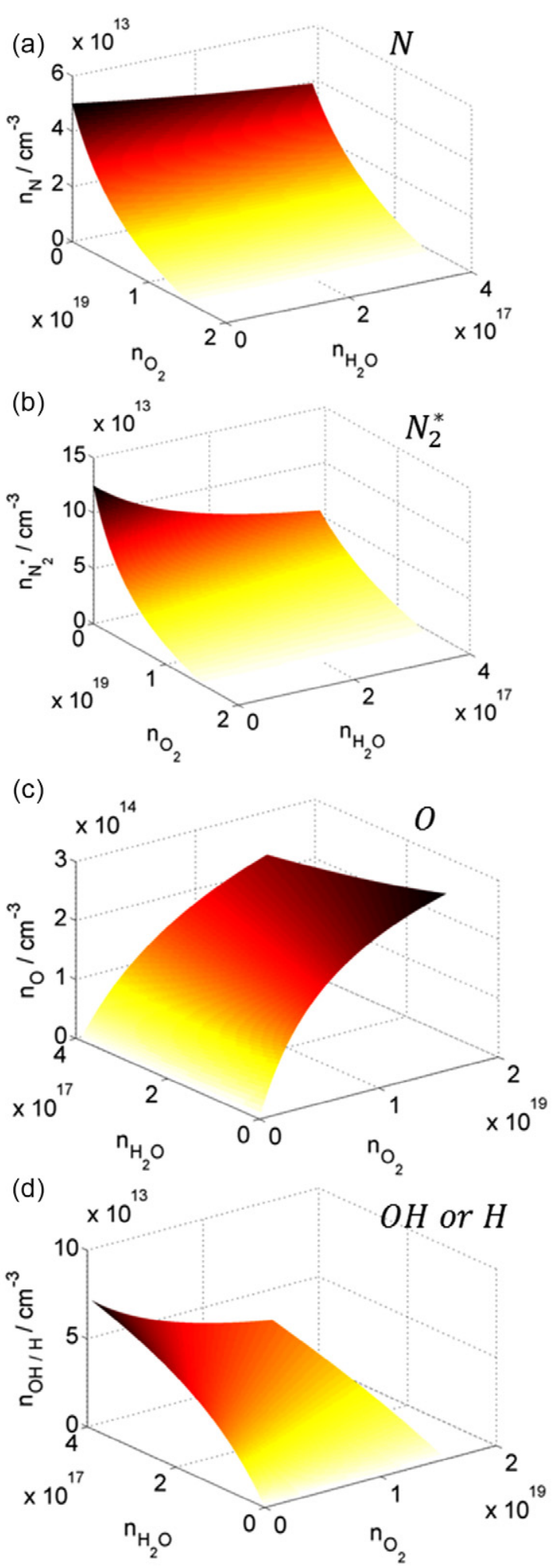

Figure 3. Initial densities of $\mathrm{N}, \mathrm{N}_{2}^{*}, \mathrm{O}$ and $\mathrm{OH} / \mathrm{H}$ due to the reaction of $\mathrm{Ar}_{2}^{*}$ and $\mathrm{Ar}^{*}$ with air species according to equations (12)-(15). The densities serve as initial values for the presented gas phase simulations. Note that $(c)$ and $(d)$ are turned in the $x-y$ plane for better readability.

the velocity field and diffusion coefficient from the previous calculation.

At the inlet of the mixing cell a short Gaussian pulse $c_{\text {In }}(t) \sim \exp \left(-\left(t / t_{0}\right)^{2}\right)$ with duration of $t_{0}=10 \mathrm{~ms}$ is applied.

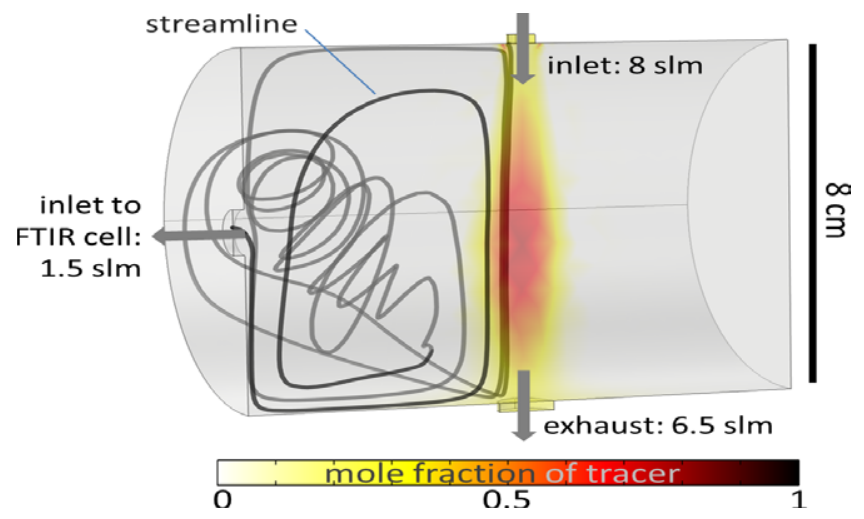

Figure 4. CFD simulation of the distribution of a tracer species inserted in the glass chamber, the stage before the FTIR MPC. The streamline indicates a typical recycling that particles entering the mixing cell undergo, which prolongs their residence time in this cell.

The impulse response is determined by evaluating the mass flow of the tracer species through the inlet of the mixing cell. The symmetry of the mixing cell can be exploited in order to halve the simulation domain and reduce the computation time, as can be seen in figure 4 .

\section{Results and discussion}

\subsection{Timescales derived from CFD simulation of the mixing cell}

In figure 4 a snapshot of the tracer distribution in the mixing cell after $0.1 \mathrm{~s}$ is shown. In the simulation, the detailed geometry of the kinpen 09 and the shielding gas device was not resolved as in the simulation shown previously in figure 1, but simplified by a circular inlet through which a mass flow of $8 \mathrm{slm}$ air enters the mixing cell. The differences in viscosity and mass of the different mixtures are assumed to be negligible for this study and thus the respective values for air are applied.

The streamline drawn in figure 4 shows that particles originating from the inlet may recirculate in the glass chamber several times before entering the FTIR cell, thus prolonging the period before they are actually measured. This explains the observed impulse response at the inlet of the FTIR MPC: as can be seen in the inset of figure 5, a first sharp pulse after $0.1 \mathrm{~s}$ the particles remaining in the mixing cell may recirculate and enter the FTIR after $0.4 \mathrm{~s}$. Most particles however, more than $95 \%$, stay in the mixing cell for a few seconds. While the tracer pulse diffuses and disperses in the mixing cell, the tracer concentration and the pulse response assume an exponential decay, which is fully developed after $2 \mathrm{~s}$.

The impulse response $w(t)$ shown in figure 5 is normalized to unity and used as a weighting function for the evaluation of the gas phase simulation. The densities $n_{i}(t)$ of species $i$ obtained from the simulation are weighted according to $n_{i}=\int \mathrm{d} t w(t) n_{i}(t)$.

The time the particles spend in the MPC is assumed to be negligible. In spite of its larger volume of 151 , the typical timescale during which it is expected to be flushed at a flux of $1.5 \mathrm{slm}$ and a pressure of $100 \mathrm{mbar}$ is one minute. However, due to the reduced pressure, two body collisions are slowed 


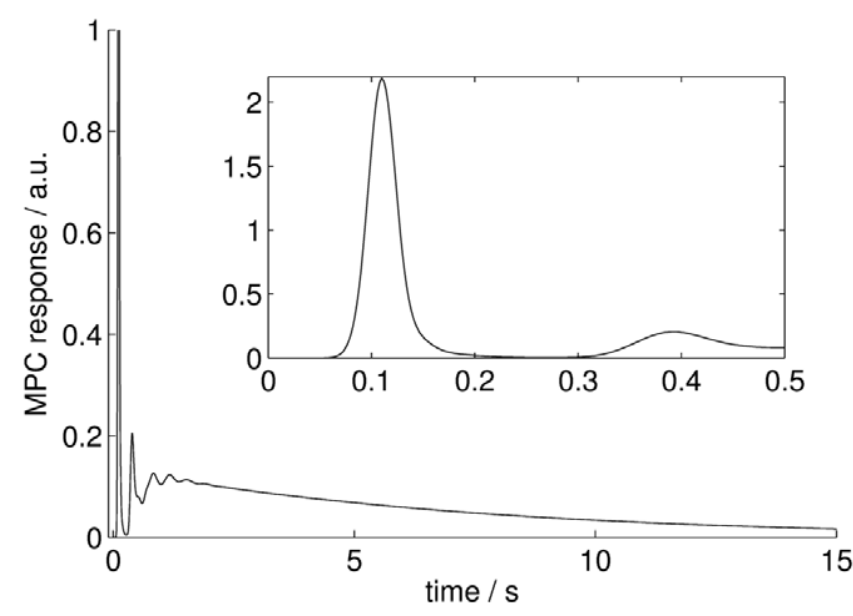

Figure 5. Impulse response at the MPC inlet; recirculation manifested in pulses at 0.1 and $0.4 \mathrm{~s}$. The full frame shows the exponential decay of the impulse response for $t>2 \mathrm{~s}$ while the inset resolves the full height of the first pulse.

down by a factor of 100 and three body collisions by a factor of 1000. Therefore, a further effect of the residence time in the MPC is not expected.

\subsection{FTIR densities and simulation}

In figure 6 the transmission signals of two infrared spectral regions are depicted. The clear absorptions occurring in these regions are attributed to ozone and nitrogen dioxide. Other species such as nitric acid $\left(\mathrm{HNO}_{3}\right)$ or $\mathrm{H}_{2} \mathrm{O}_{2}$ are also identified, but owing to their weak absorption signal a serious quantitative evaluation is not feasible [30].

The absorption profiles of $\mathrm{O}_{3}$ and $\mathrm{NO}_{2}$ in figure 6 are both influenced by the shielding gas composition. For both species, no absorption is found when the shielding gas consists of nitrogen only. However, when increasing the oxygen concentration a different behaviour evolves. While the $\mathrm{O}_{3}$ absorption steadily increases with increasing oxygen content in the shielding gas, an indifferent behaviour is found for $\mathrm{NO}_{2}$. The $\mathrm{NO}_{2}$ absorption increases with increasing oxygen concentration but only up to a certain level. When the oxygen concentration exceeds this level the absorption signal decreases again. Besides the impact of different oxygen/nitrogen ratios, shielding gas humidity also affects the absorption signals (not shown in figure 6). In order to explain the behaviour of $\mathrm{O}_{3}$ and $\mathrm{NO}_{2}$ for these varying conditions the concentration of both species is calculated from the measured absorption profiles and compared with the results of the gas phase simulation. In figure 7 the ozone and nitrogen dioxide concentration obtained by FTIR spectroscopy and computed with the gas phase simulation is shown for different shielding gas compositions. Figure 7( $a$ ) shows a shielding gas variation from $100 \% \mathrm{O}_{2}$ and $0 \% \mathrm{~N}_{2}$ to $0 \% \mathrm{O}_{2}$ and $100 \% \mathrm{~N}_{2}$ in dry conditions. As indicated by the absorption profiles, the ozone density continuously rises with the amount of oxygen in the shielding gas, while the nitrogen dioxide densities are minimal at $0 \%$ oxygen or $0 \%$ nitrogen and have a maximum at around $30 \%$ oxygen. The remaining $\mathrm{NO}_{2}$ density measured at $0 \%$ nitrogen presumably originates from impurities in the employed gas. The simulated curves of the $\mathrm{O}_{3}$ and $\mathrm{NO}_{2}$ densities were fitted against the experimentally obtained values using the initial argon metastable and argon excimer densities as fitting parameters. The obtained initial densities $n_{\mathrm{Ar}^{*}}=$ $0.5 \times 10^{14} \mathrm{~cm}^{-3}$ and $n_{\mathrm{Ar}_{2}^{*}}=1 \times 10^{14} \mathrm{~cm}^{-3}$ are certainly overestimated, as in the model the argon metastables and excimers are produced instantaneously. The fitted initial values therefore correspond to the total number of produced argon metastables and excimers produced by several pulses and not to actual densities that can be expected in the effluent. Also, electronic dissociation and excitation processes are likely to contribute to the generation of secondary species. In a simulation of a similar jet, argon metastable and excimer densities do not exceed $n_{\mathrm{Ar}^{*}}=10^{12} \mathrm{~cm}^{-3}$ and $n_{\mathrm{Ar}^{*}}=$ $10^{13} \mathrm{~cm}^{-3}$ [11]. Figures $7(b)$ and $(c)$ again show shielding gas variations from pure oxygen to pure nitrogen, but at a relative humidity of $18 \%(b)$ and $36 \%(c)$. The agreement between the experimental data and the simulation is best at a relative humidity of $36 \%$. While the amount of ozone produced drops with rising humidity, the nitrogen dioxide production remains constant. In both experimental data and simulation the maximum of $\mathrm{NO}_{2}$ production shifts towards lower oxygen concentrations at higher humidity. In dry conditions, the $\mathrm{NO}_{2}$ production is overestimated by the model, and both the simulated $\mathrm{O}_{3}$ and $\mathrm{NO}_{2}$ curves deviate from the measured data. The cause for this could be either water impurities in the feed gas, which may amount to $3 \mathrm{ppm}$ (according to the manufacturer [37]) and are not considered in the model, or that in the absence of water other reaction pathways that are not considered in the current model become important. The $\mathrm{NO}_{2}$ density obtained in this work agrees very well with the far-field density of $8 \times 10^{12} \mathrm{~cm}^{-3}$ obtained by Iseni et al by the infrared absorption technique using a quantum cascade laser for the kinpen 09. In the simulation shown in figure $7(d)$ the mixing ratio of oxygen to nitrogen is set to 20/80 (artificial air), while the humidity of the shielding gas is varied. The drop in the net ozone production observed in the experimental data agrees remarkably well with the simulation. Note that for all simulations presented in this work the same initial argon metastable and excimer densities are used, and only the shielding gas composition is varied. In figure $7(d)$ an additional numerical study is shown, in which the role of oxygen metastables $\mathrm{O}_{2}^{*}$ and the excited atomic oxygen state $\mathrm{O}^{*}$ is investigated for stability analysis. The density of $\mathrm{O}_{2}^{*}$ was initialized using an excitation degree of $0.1 \%$ of the oxygen density based on the simulation study [11], while for the atomic oxygen $50 \%$ of the atoms were initialized as ground state $\mathrm{O}$ and $50 \%$ as $\mathrm{O}^{*}$. The respective branching ratio for dissociation of $\mathrm{O}_{2}$ by $\mathrm{Ar}^{*}$ can be expected to be $27 \% \mathrm{O}^{*}, 73 \% \mathrm{O}$ based on the rate coefficients found in [38]; however, a higher $\mathrm{O}^{*}$ was assumed, as further excitation processes are neglected. Note that in all previous studies $\mathrm{O}_{2}^{*}$ and $\mathrm{O}^{*}$ were initialized with density zero. From figure $7(d)$ it is clear that the addition of both species does not significantly affect the dynamics of ozone and nitrogen dioxide upon shielding gas variation, which is the reason why they were excluded from the base cases as they would yield bad fitting parameters. Although $\mathrm{O}_{2}^{*}$ does destroy a significant amount of ozone via reaction (R3), this 

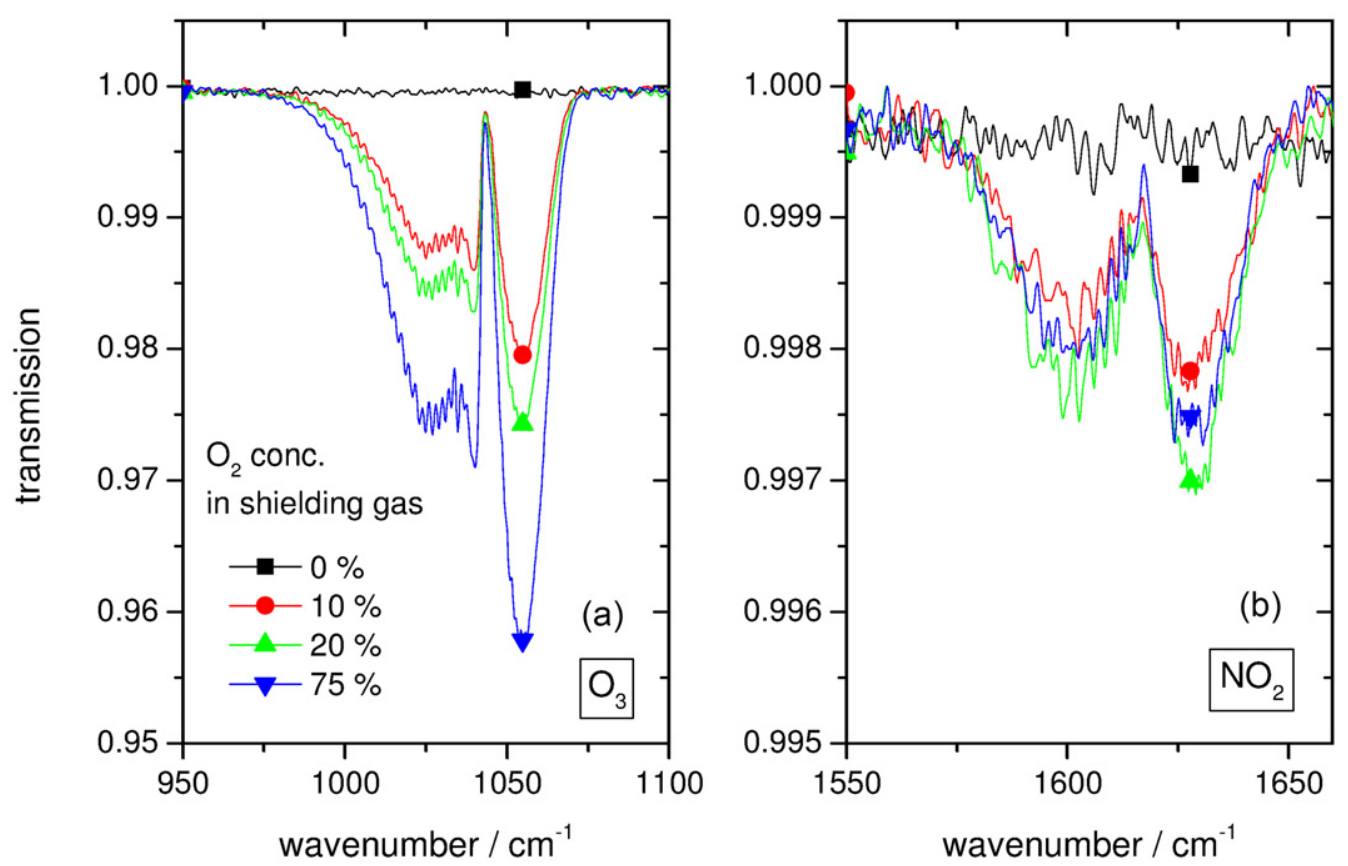

Figure 6. FTIR absorption spectra for $\mathrm{O}_{3}$ and $\mathrm{NO}_{2}$ at different oxygen concentrations in the shielding gas.

reaction produces atomic oxygen, most of which is recycled to ozone via reaction ( $\mathrm{R} 8)$. O* was considered in the study, as it may play a role in the destruction of ozone via reactions (R37) and (R38); however, in the model, quenching of $\mathrm{O}^{*}$ to ground state atomic oxygen was more effective.

In figure 8 the temporal development of atomic oxygen, ozone, atomic nitrogen, nitrogen metastable, nitric oxide (NO), nitrogen dioxide, hydroxide, hydrogen peroxide, nitric acid and nitrous acid $\left(\mathrm{HNO}_{2}\right)$ is shown. As discussed in the previous section, due to the mixing cell the species reach the FTIR MPC after $0.1 \mathrm{~s}$ or more. From the kinetic simulations ozone and nitrogen dioxide can be expected to have reached a fairly stable level by this time, which is advantageous for the interpretation of the experimental data, as the conversion from short living species to $\mathrm{O}_{3}$ and $\mathrm{NO}_{2}$ is almost completed. The temporal evolution also shows that in the active effluent other neutral species than $\mathrm{O}_{3}$ and $\mathrm{NO}_{2}$ can be present in significant amounts: large fractions of $\mathrm{O}_{3}, \mathrm{NO}_{2}$ or $\mathrm{H}_{2} \mathrm{O}_{2}$ have not been generated yet and the respective preceding species (e.g. O, NO and $\mathrm{OH}$ or $\mathrm{HO}_{2}$ ) can be expected in significant amounts. The concentration of nitrogen dioxide and ozone measured in the far field may therefore be significantly higher than the one present in the effluent. It is noted that the temporal evolution of species shown should not directly be converted to a spatial distribution in the effluent region, as the initial generation and destruction processes are modelled to occur instantaneously. The instantaneous initialization mimics the fast dissociation and excitation processes caused by a single plasma bullet hitting a given volume element. More detailed models should, however, include multiple pulses, which is not feasible in the current zero dimensional model. While atomic oxygen is known to be stable for milliseconds and reach distances of several centimetres in the effluent of plasma jets [39], in the current model it is consumed after approximately $0.2 \mathrm{~ms}$ by the reaction with $\mathrm{O}_{2}$, forming $\mathrm{O}_{3}$ via reaction (R8). This occurs as the shielding gas density rises instantaneously in the current model. Especially in the centre of the stream where shielding gas densities are low (see figure 1), the lifetime of oxygen can be expected to be significantly longer.

From figure 8 it is evident that only the two long living species with the highest densities were detected. From the model, the stable species with the third highest density is hydrogen peroxide. The $\mathrm{H}_{2} \mathrm{O}_{2}$ density in the far field of a kinpen 09 has recently been detected via FTIR spectroscopy at higher pressure to be in the range of about $5 \times 10^{12} \mathrm{~cm}^{3}$ and the $\mathrm{HNO}_{3}$ density was found to be in the range of $3 \times 10^{12} \mathrm{~cm}^{3}$, which is in perfect agreement with the current model [30]. Verreyken et al have obtained an $\mathrm{OH}$ density of the order of $10^{14} \mathrm{~cm}^{-3}$ in the effluent of a kinpen 09 by LIF measurements with admixture of $400 \mathrm{ppm}$ water in the feed gas [22]. The lower $\mathrm{OH}$ values obtained in our simulation (of the order of $10^{13} \mathrm{~cm}^{-3}$ ) are expected, as the feed gas humidity in our experimental setup was measured to be lower than $20 \mathrm{ppm}$ [40].

Pipa et al have measured the $\mathrm{NO}$ and $\mathrm{NO}_{2}$ density produced by a kinpen operated at a higher frequency $(1.4 \mathrm{MHz})$ and higher gas flow rates with air admixture in the feed gas [41]. The density was measured in a multipass cell with $100 \mathrm{~m}$ absorption length using tunable diode laser absorption spectroscopy in the infrared. They obtained both $\mathrm{NO}$ and $\mathrm{NO}_{2}$ densities in the range of some $10^{13} \mathrm{~cm}^{-3}$. Again, the maximum $\mathrm{NO}$ and $\mathrm{NO}_{2}$ densities predicted by the current model are lower, as can be expected as no molecular admixtures are used. NO is not stable enough to be measured directly with the current experimental setup. However, it can be measured directly in the effluent of plasma jets using laser induced fluorescence as presented by van Gessel et al who found NO densities in the range of $10^{14} \mathrm{~cm}^{-3}$ in an argon operated plasma jet [39]. 


\section{(a)}
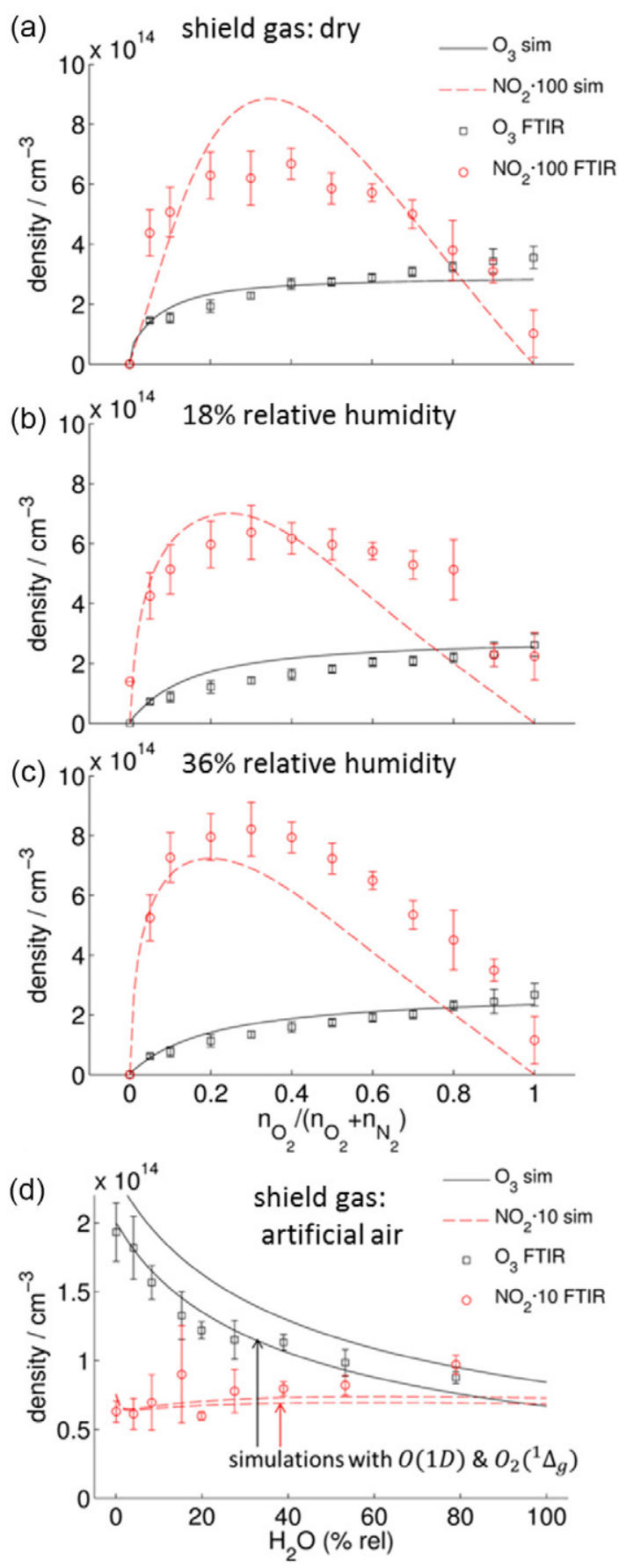

Figure 7. Density of ozone and nitrogen dioxide upon oxygen to nitrogen shielding gas variation $(a)-(c)$ at different humidity levels and humidity variation at $\mathrm{O}_{2} / \mathrm{N}_{2}=20 / 80(d)$. $(d)$ includes an additional study of the influence of $\mathrm{O}^{*}$ and $\mathrm{O}_{2}^{*}$.

\subsection{Evaluation of reaction dynamics: variation of shielding gas composition}

Figures 9-11 show the dynamics of the most important generation and destruction processes for $\mathrm{NO}_{2}, \mathrm{NO}$ and atomic oxygen as computed by the model. The plotted densities are the total densities of the respective species produced (positive values) or destroyed (negative values) by the given reaction. While the data shown in this section cannot be verified experimentally, they serve to gain insight into the cause

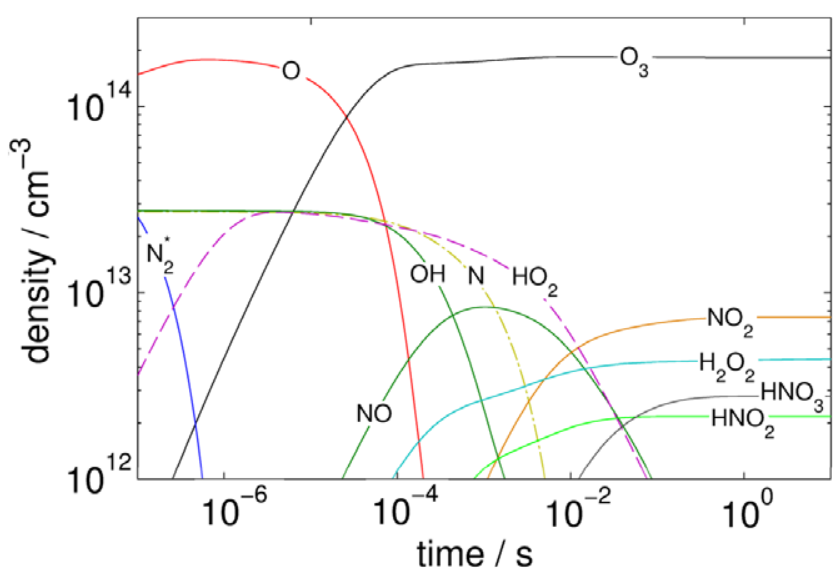

Figure 8. Temporal development of several species. The shielding gas in the simulation is artificial air with a relative humidity of $18 \%$.

of the dynamics of reactive species production upon shielding gas variation.

3.3.1. Generation/destruction of $\mathrm{NO}_{2}$. In figure $9(a)$ the main generation and destruction mechanisms for $\mathrm{NO}_{2}$ upon oxygen to nitrogen shielding gas variation at a relative humidity of $18 \%$ are shown. Pointwise summation of the three plotted curves yields the $\mathrm{NO}_{2}$ dynamics simulated and measured in figure $7(a) . \mathrm{NO}_{2}$ is mainly produced via reactions (R22) and (R24) from $\mathrm{NO}$ reacting with $\mathrm{O}_{3}$ or $\mathrm{HO}_{2}$. The contribution of $\mathrm{HO}_{2}$ explains why the maximum of net $\mathrm{NO}_{2}$ production shifts towards lower oxygen content in the shielding gas when the humidity is increased (see figure $7(a)-(c)$ ): $\mathrm{HO}_{2}$ is mainly formed via the three body reaction (R16) of $\mathrm{H}$ and $\mathrm{O}_{2}$. The production of hydrogen is in turn assumed to be dominated by the dissociation of water by reactions (8) and (11). While the absolute concentration of $\mathrm{NO}_{2}$ remains almost unchanged upon humidity variation (see figure $7(d)$, the underlying generation and destruction mechanisms may well involve a dynamic behaviour as shown in figure $9(b)$. The most important loss reaction (R15) for $\mathrm{NO}_{2}$ via $\mathrm{OH}$ is a main source for $\mathrm{HNO}_{3}$.

It is noted that the production of $\mathrm{NO}_{2}$ from $\mathrm{NO}$ and $\mathrm{O}$ (R21) may be underestimated in the current model, as atomic oxygen is already consumed before NO reaches its maximum density.

3.3.2. Generation/destruction of $\mathrm{NO}$. As $\mathrm{NO}_{2}$ is mainly produced via NO, we also briefly discuss the mechanisms for the NO generation and destruction shown in figure 10. It is noted that for the generation of NO atomic nitrogen is the key species in the model. Two pairs of generation and destruction mechanisms revealing the same dynamics can be distinguished: on the one hand generation of $\mathrm{NO}$ via $\mathrm{N}$ with $\mathrm{OH}$ (R5) and destruction by $\mathrm{N}$ (R6), both depending on the atomic nitrogen density; on the other hand $\mathrm{NO}$ can be generated via reaction of $\mathrm{N}$ with $\mathrm{O}_{2}(\mathrm{R} 7)$ and destroyed by $\mathrm{HO}_{2}(\mathrm{R} 24)$. Here both mechanisms require the presence of $\mathrm{O}_{2}$ (as $\mathrm{HO}_{2}$ is generated from $\mathrm{H}$ and $\mathrm{HO}_{2}$; see (R16)). 

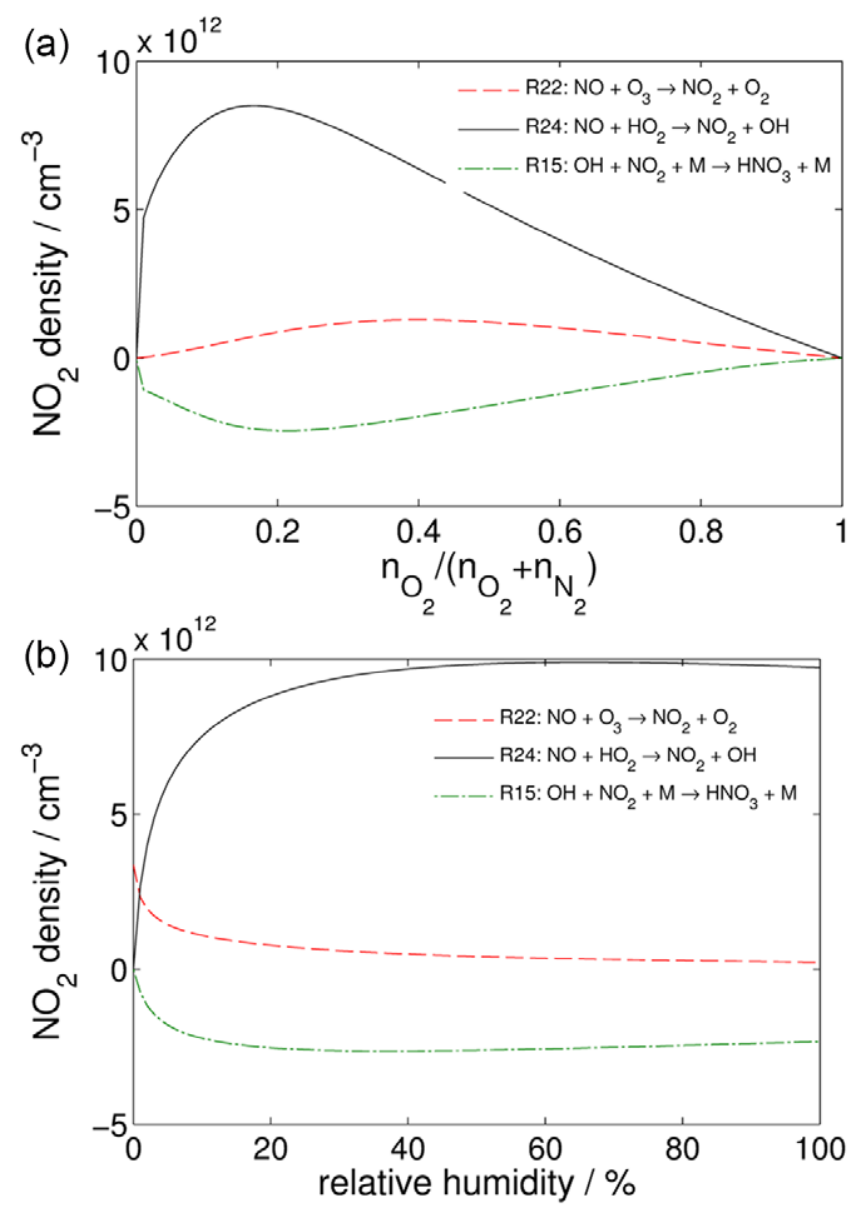

Figure 9. Most important generation and destruction mechanisms for $\mathrm{NO}_{2}$.

3.3.3. Generation/destruction of $\mathrm{O}$ and $\mathrm{O}_{3}$. The generation and destruction dynamics for atomic oxygen are shown in figure 11. In the current model two generation processes are important: first, the initial density due to dissociation of $\mathrm{O}_{2}$ by excited argon species according to (12); second, the very effective dissociation of $\mathrm{O}_{2}$ by $\mathrm{N}_{2}^{*}$, which is the reason why high ozone concentrations can be observed at low oxygen shield gas concentrations. The most important destruction mechanism for atomic oxygen is the three body reaction with $\mathrm{O}_{2}$ and another arbitrary reaction partner (R8). This reaction also directly determines the density of ozone obtained. If $\mathrm{O}_{2}^{*}$ is included in the model, an additional destruction of $\mathrm{O}_{3}$ via reaction $(\mathrm{R} 3)$ is observed. However, as the destruction of ozone by $\mathrm{O}_{2}^{*}$ recycles atomic oxygen, the net ozone production observed in figure $7(d)$ is not significantly affected by the addition of $\mathrm{O}_{2}^{*}$ in the model.

\subsection{Influence of ambient humidity on water related species}

As atmospheric pressure plasma sources for biomedical applications are usually operated in open air, the effect of the ambient humidity on various species produced by the plasma is investigated numerically. In figure 12 the relative density of various water related species is evaluated upon humidity variation of the shielding gas after a simulation time of $1 \mathrm{~ms}$,
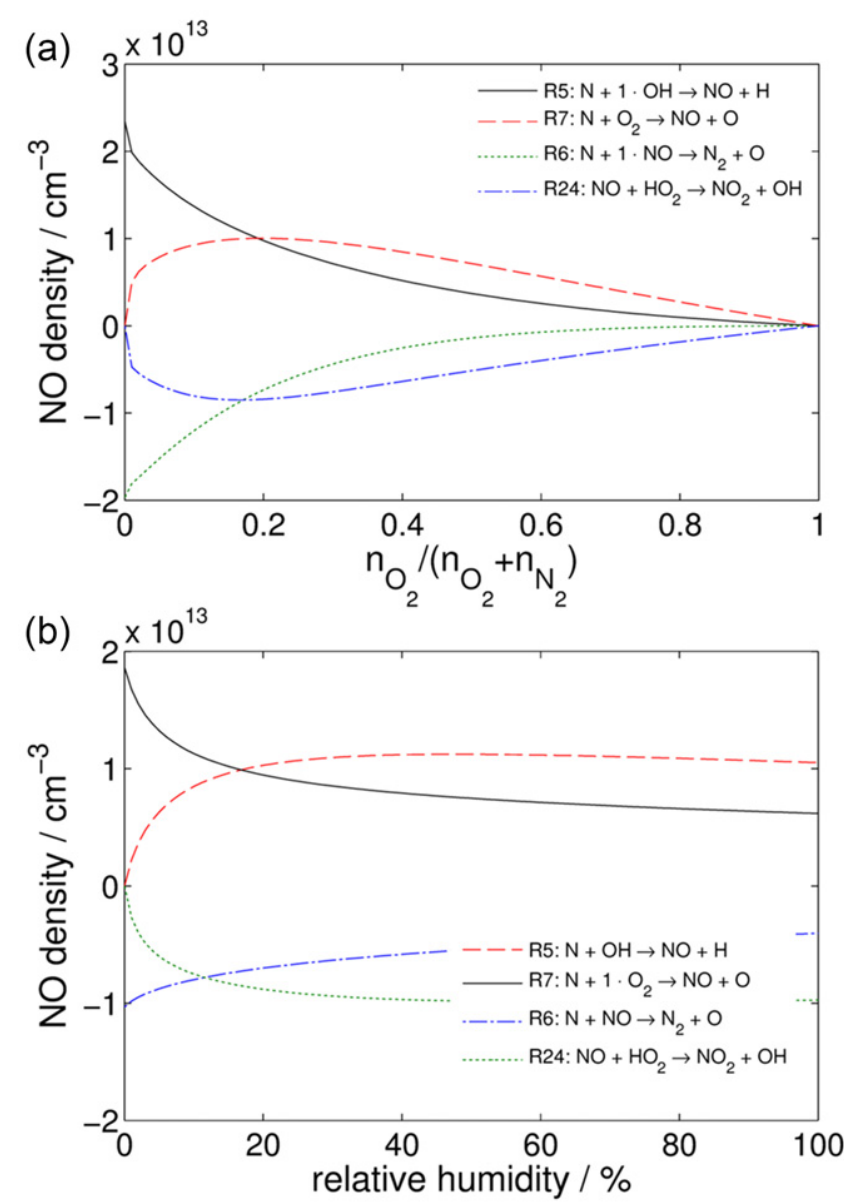

Figure 10. Most important generation and destruction mechanisms for NO.

while the $\mathrm{O}_{2} / \mathrm{N}_{2}$ ratio is kept at $20 / 80$. The relative densities (normalized to the respective maximum value) are evaluated after a simulation time of $10^{-3} \mathrm{~s}$. The species evaluated in figure 12 have already been detected experimentally in liquid medium (Dulbecco's phosphate buffered saline) after plasma treatment with an identical plasma jet, and are of special relevance for their biological effects. The $\mathrm{OH}$ radical and superoxide anion $\mathrm{O}_{2}^{-}$(which may be produced by dissolution of $\mathrm{HO}_{2}$ ) were detected by electron paramagnetic resonance spectroscopy [10], nitrite and nitrate (which may be produced by dissolution of $\mathrm{HNO}_{2}$ and $\mathrm{HNO}_{3}$ ) by colorimetric assays and $\mathrm{H}_{2} \mathrm{O}_{2}$ using test stripes [30,40]. Although the data shown in figure 12 are only of qualitative nature, as the current study mainly focuses on the far field production of $\mathrm{O}_{3}$ and $\mathrm{NO}_{2}$, it indicates that the relative humidity, which often varies between 20 and $100 \%$ within a day in most locations, may have a significant impact on the plasma chemistry of CAP jets.

\section{Summary and conclusion}

The effect of shielding gas variations on the reactive species generation of a CAP jet has been investigated by the combination of FTIR measurements and zero dimensional kinetic simulations. 


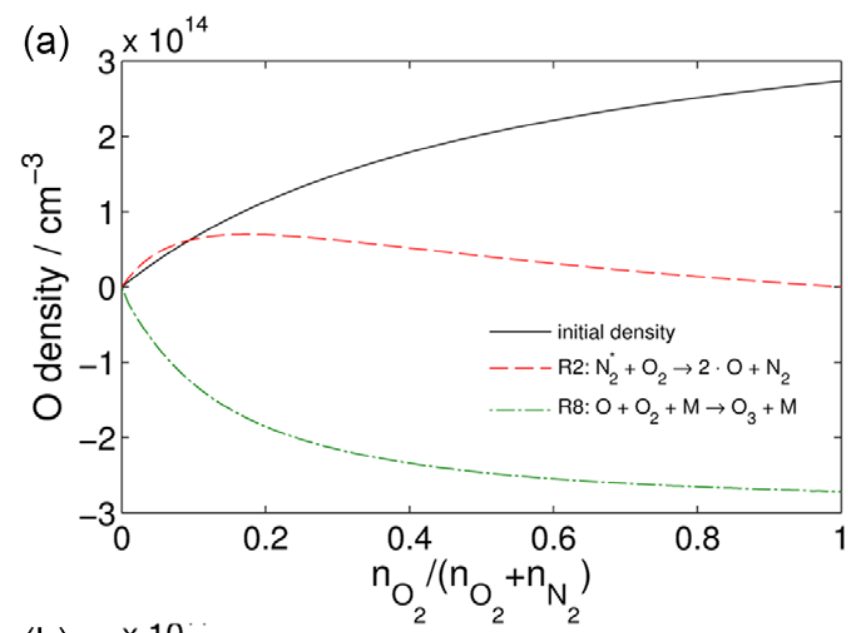

(b) $2 \times 10$

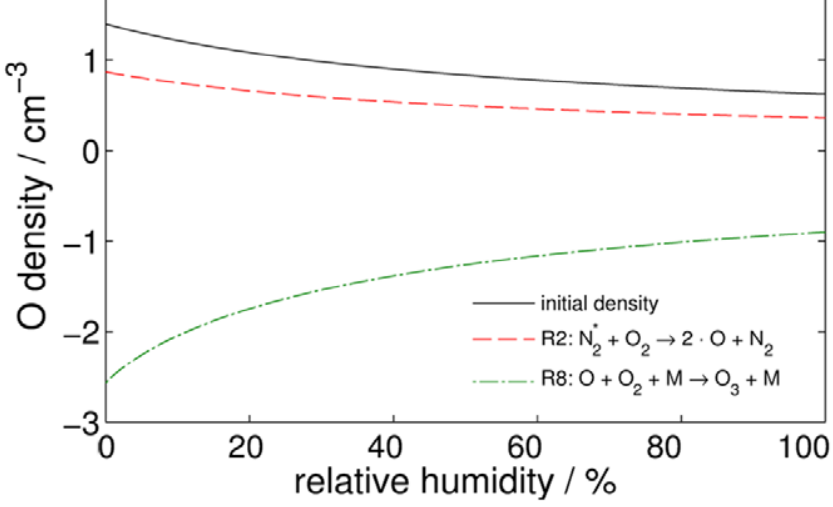

Figure 11. Most important generation and destruction mechanisms for $\mathrm{O}$.

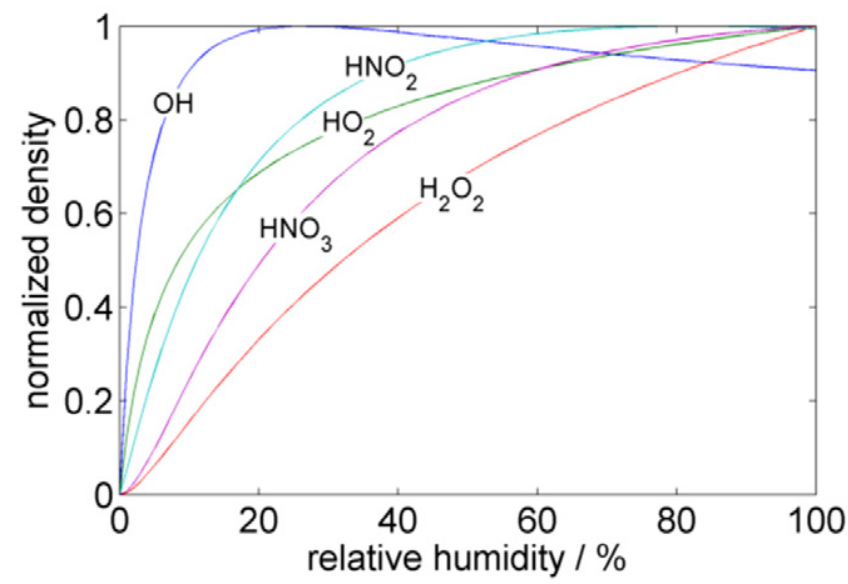

Figure 12. Relative densities of water-related species upon humidity variation in the shielding gas according to the simulation.

As both the oxygen to nitrogen ratio and the humidity concentration of the shielding gas were varied, the FTIR measurements yielded two dimensional datasets for the ozone and nitrogen dioxide densities.

The kinetic model was designed to have only two free fitting parameters: the initial densities of argon metastables and argon excimers. These were used to fit the ozone and nitrogen dioxide densities obtained from the simulations to the experimental data. Shielding gas variations have proven to be a valuable tool for the validation of the kinetic simulations, which in turn give insight into the relevant reaction pathways.

The gas flow from the CAP jet to the FTIR MPC was modelled by CFD simulations in order to determine the correct evaluation time of the kinetic simulations. It was shown that particles travel for at least $0.1 \mathrm{~s}$ before they enter the MPC.

In the FTIR experiments and kinetic simulation maximum ozone densities of about $3 \times 10^{14} \mathrm{~cm}^{-3}$ were obtained. Ozone continuously increases with the amount of oxygen in the shielding gas. However, even at low oxygen admixture significant amounts of ozone are produced, as nitrogen metastables effectively contribute to the ozone production. With rising humidity, the amount of ozone produced by the jet is halved. The simulations suggest that this is mainly due to the fact that chemical energy is spent on the dissociation of water molecules, and thus less energy is available for the dissociation of oxygen and excitation of nitrogen (which in turn contribute to the creation of ozone). The maximum nitrogen dioxide production amounts to $6 \times 10^{12} \mathrm{~cm}^{-3}$. The lowest amount of nitrogen dioxide is produced at zero percent oxygen and zero percent nitrogen, as the formation of nitrogen dioxide naturally requires both molecules to be present. The maximum production occurs at around $40 \%$ oxygen in dry conditions. The maximum shifts towards lower oxygen concentrations as the humidity in the shielding gas increases. Simulations suggest that this occurs as $\mathrm{HO}_{2}$ is involved in the creation of nitrogen dioxide. $\mathrm{HO}_{2}$ in turn requires water and oxygen to be present.

Various species, namely $\mathrm{OH}, \mathrm{H}_{2} \mathrm{O}_{2}, \mathrm{HNO}_{2}, \mathrm{HNO}_{3}$ and $\mathrm{HO}_{2}$, which may be relevant for biomedical applications of plasmas, were evaluated for their dependence on the humidity in the shielding gas. The ambient humidity has a significant impact on the densities of these species. Controlling the environment of atmospheric pressure plasma sources may therefore help improve the reproducibility of experimental studies. This may especially be relevant for experimental studies in the field of plasma medicine, where biological deviations add up to deviations in the reactive species output in the applied sources. Also, varying the ratio of oxygen and nitrogen in the shielding gas, the cocktail of reactive oxygen and nitrogen species can not only be tuned to an optimal value for the given application, but also be altered continuously in order to perform parametric studies in experiments in the field of plasma medicine.

\section{Acknowledgment}

This work is funded by the German Federal Ministry of Education and Research (Grant No 03Z2DN12). 


\section{Appendix. Chemical reactions}

Table 1. List of rate coefficients used in the gas phase kinetic simulation, evaluated for a temperature of $300 \mathrm{~K}$. The rate coefficients are given in units of $\mathrm{s}^{-1}, \mathrm{~cm}^{3} \mathrm{~s}^{-1}$ and $\mathrm{cm}^{6} \mathrm{~s}^{-1}$ for first, second and third order reactions.

\begin{tabular}{|c|c|c|c|}
\hline ID & Reaction & Rate Coeff. & Ref. \\
\hline (R1) & $\mathrm{N}_{2}^{*}+\mathrm{N}_{2} \rightarrow 2 \mathrm{~N}_{2}$ & $1.9 \times 10^{-13}$ & [42] \\
\hline (R2) & $\mathrm{N}_{2}^{*}+\mathrm{O}_{2} \rightarrow 2 \mathrm{O}+\mathrm{N}_{2}$ & $1.5 \times 10^{-12}$ & {$[42]$} \\
\hline (R3) & $\mathrm{O}_{2}^{*}+\mathrm{O}_{3} \rightarrow \mathrm{O}+2 \mathrm{O}_{2}$ & $3.8 \times 10^{-15}$ & [43] \\
\hline (R4) & $\mathrm{O}_{2}^{*}+\mathrm{N}_{2} \rightarrow \mathrm{O}_{2}+\mathrm{N}_{2}$ & $1.5 \times 10^{-18}$ & [42] \\
\hline (R5) & $\mathrm{N}+\mathrm{OH} \rightarrow \mathrm{NO}+\mathrm{H}$ & $4.7 \times 10^{-11}$ & [44] \\
\hline (R6) & $\mathrm{N}+\mathrm{NO} \rightarrow \mathrm{N}_{2}+\mathrm{O}$ & $2.9 \times 10^{-11}$ & [43] \\
\hline (R7) & $\mathrm{N}+\mathrm{O}_{2} \rightarrow \mathrm{NO}+\mathrm{O}$ & $8.5 \times 10^{-17}$ & [43] \\
\hline (R8) & $\mathrm{O}+\mathrm{O}_{2}+M \rightarrow \mathrm{O}_{3}+M$ & $3.4 \times 10^{-10}$ & [42] \\
\hline (R9) & $\mathrm{O}+\mathrm{OH} \rightarrow \mathrm{H}+\mathrm{O}_{2}$ & $3.5 \times 10^{-11}$ & [45] \\
\hline (R10) & $\mathrm{O}+\mathrm{O}_{3} \rightarrow 2 \mathrm{O}_{2}$ & $8 \times 10^{-15}$ & [45] \\
\hline (R11) & $\mathrm{H}+\mathrm{O}_{3} \rightarrow \mathrm{OH}+\mathrm{O}_{2}$ & $2.9 \times 10^{-11}$ & [43] \\
\hline (R12) & $\mathrm{O}+\mathrm{HO}_{2} \rightarrow \mathrm{OH}+\mathrm{O}_{2}$ & $5.8 \times 10^{-11}$ & {$[45]$} \\
\hline (R13) & $\mathrm{OH}+\mathrm{HO}_{2} \rightarrow \mathrm{H}_{2} \mathrm{O}+\mathrm{O}_{2}$ & $1.1 \times 10^{-10}$ & [45] \\
\hline (R14) & $\mathrm{OH}+\mathrm{O}_{3} \rightarrow \mathrm{HO}_{2}+\mathrm{O}_{2}$ & $7.3 \times 10^{-14}$ & [45] \\
\hline (R15) & $\mathrm{OH}+\mathrm{NO}_{2}+M \rightarrow \mathrm{HNO}_{3}+M$ & $1.9 \times 10^{-30}$ & [42] \\
\hline (R16) & $\mathrm{H}+\mathrm{O}_{2}+M \rightarrow \mathrm{HO}_{2}+M$ & $5.7 \times 10^{-32}$ & [43] \\
\hline (R17) & $2 \mathrm{HO}_{2}+M \rightarrow \mathrm{H}_{2} \mathrm{O}_{2}+\mathrm{O}_{2}+M$ & $4.9 \times 10^{-32}$ & [43] \\
\hline (R18) & $2 \mathrm{OH}+M \rightarrow \mathrm{H}_{2} \mathrm{O}_{2}+M$ & $6.2 \times 10^{-31}$ & [43] \\
\hline (R19) & $\mathrm{H}_{2} \mathrm{O}_{2}+\mathrm{OH} \rightarrow \mathrm{H}_{2} \mathrm{O}+\mathrm{HO}_{2}$ & $1.7 \times 10^{-12}$ & {$[45]$} \\
\hline (R20) & $\mathrm{O}+\mathrm{NO}_{2} \rightarrow \mathrm{NO}+\mathrm{O}_{2}$ & $9.7 \times 10^{-12}$ & {$[43]$} \\
\hline$(\mathrm{R} 21)$ & $\mathrm{NO}+\mathrm{O}+M \rightarrow \mathrm{NO}_{2}+M$ & $9 \times 10^{-32}$ & [43] \\
\hline (R22) & $\mathrm{NO}+\mathrm{O}_{3} \rightarrow \mathrm{NO}_{2}+\mathrm{O}_{2}$ & $1.7 \times 10^{-14}$ & [45] \\
\hline (R23) & $\mathrm{NO}+\mathrm{OH}+M \rightarrow \mathrm{HNO}_{2}+M$ & $7 \times 10^{-31}$ & [43] \\
\hline (R24) & $\mathrm{NO}+\mathrm{HO}_{2} \rightarrow \mathrm{NO}_{2}+\mathrm{OH}$ & $8.8 \times 10^{-12}$ & [45] \\
\hline (R25) & $\mathrm{OH}+\mathrm{HNO}_{2} \rightarrow \mathrm{NO}_{2}+\mathrm{H}_{2} \mathrm{O}$ & $6 \times 10^{-12}$ & [45] \\
\hline (R26) & $\mathrm{NO}_{2}+\mathrm{N} \rightarrow \mathrm{N}_{2} \mathrm{O}+\mathrm{O}$ & $1.2 \times 10^{-11}$ & [43] \\
\hline (R27) & $\mathrm{NO}_{2}+\mathrm{O}+M \rightarrow \mathrm{NO}_{3}+M$ & $9 \times 10^{-32}$ & {$[43]$} \\
\hline (R28) & $\mathrm{OH}+\mathrm{HNO}_{3} \rightarrow \mathrm{NO}_{3}+\mathrm{H}_{2} \mathrm{O}$ & $1.5 \times 10^{-13}$ & [46] \\
\hline (R29) & $\mathrm{NO}_{3}+\mathrm{NO}_{2}+M \rightarrow \mathrm{N}_{2} \mathrm{O}_{5}+M$ & $2.7 \times 10^{-30}$ & [47] \\
\hline (R30) & $\mathrm{N}_{2} \mathrm{O}_{5} \rightarrow \mathrm{NO}_{3}+\mathrm{NO}_{2}$ & 0.07 & [45] \\
\hline (R31) & $2 \mathrm{H}+M \rightarrow \mathrm{H}_{2}+M$ & $8.9 \times 10^{-33}$ & {$[48]$} \\
\hline (R32) & $\mathrm{N}_{2}^{*}+\mathrm{O} \rightarrow \mathrm{O}^{*}+\mathrm{N}_{2}$ & $2.3 \times 10^{-11}$ & {$[15]$} \\
\hline (R33) & $\mathrm{O}^{*}+\mathrm{O}_{2} \rightarrow \mathrm{O}+\mathrm{O}_{2}$ & $8 \times 10^{-12}$ & {$[15]$} \\
\hline (R34) & $\mathrm{O}^{*}+\mathrm{O} \rightarrow 2 \mathrm{O}$ & $8 \times 10^{-12}$ & {$[15]$} \\
\hline (R35) & $\mathrm{O}^{*}+\mathrm{O}_{2}^{*} \rightarrow \mathrm{O}+\mathrm{O}_{2}$ & $10^{-11}$ & [49] \\
\hline (R36) & $\mathrm{O}^{*}+\mathrm{O}_{2}^{2} \rightarrow \mathrm{O}+\mathrm{O}_{2}^{*}$ & $10^{-12}$ & {$[15]$} \\
\hline (R37) & $\mathrm{O}^{*}+\mathrm{O}_{3} \rightarrow 2 \mathrm{O}+\mathrm{O}_{2}$ & $1.2 \times 10^{-10}$ & [43] \\
\hline (R38) & $\mathrm{O}^{*}+\mathrm{O}_{3} \rightarrow 2 \cdot \mathrm{O}_{2}$ & $1.2 \times 10^{-10}$ & {$[43]$} \\
\hline (R39) & $\mathrm{O}^{*}+\mathrm{N}_{2} \rightarrow \mathrm{O}+\mathrm{N}_{2}$ & $2.7 \times 10^{-11}$ & {$[15]$} \\
\hline (R40) & $\mathrm{O}^{*}+\mathrm{NO} \rightarrow \mathrm{O}+\mathrm{NO}$ & $4 \times 10^{-11}$ & [49] \\
\hline$(\mathrm{R} 41)$ & $\mathrm{O}^{*}+\mathrm{NO}_{2} \rightarrow \mathrm{O}_{2}+\mathrm{NO}$ & $1.3 \times 10^{-10}$ & {$[50]$} \\
\hline$(\mathrm{R} 42)$ & $\mathrm{O}^{*}+\mathrm{H}_{2} \mathrm{O} \rightarrow 2 \mathrm{OH}$ & $2.2 \times 10^{-10}$ & {$[51]$} \\
\hline
\end{tabular}

\section{References}

[1] Fridman G, Friedman G, Gutsol A, Shekhter A B, Vasilets V N and Fridman A 2008 Applied plasma medicine Plasma Process. Polym. 5 503-33

[2] Heinlin J, Morfill G, Landthaler M, Stolz W, Isbary G, Zimmermann J L, Shimizu T and Karrer S 2010 Plasma medicine: possible applications in dermatology J. Dtsch. Dermatol. Ges. 8 968-76

[3] Laroussi M, Kong M, Morfill G and Stolz W 2012 Plasma Medicine: Applications of Low-temperature Gas Plasmas in Medicine and Biology (Cambridge: Cambridge University Press)

[4] von Woedtke T, Reuter S, Masur K and Weltmann K D 2013 Plasmas for medicine Phys. Rep. 530 291-320

[5] Weltmann K-D, Polak M, Masur K, Woedtke T v, Winter J and Reuter S 2012 Plasma processes and plasma sources in medicine Contrib. Plasma Phys. 52 644-54

[6] Graves D B 2012 The emerging role of reactive oxygen and nitrogen species in redox biology and some implications for plasma applications to medicine and biology J. Phys. D: Appl. Phys. $\mathbf{4 5} 263001$

[7] Reuter S, Tresp H, Wende K, Hammer M U, Winter J, Masur K, Schmidt-Bleker A and Weltmann K-D 2012 From RONS to ROS: tailoring plasma jet treatment of skin cells IEEE Trans. Plasma Sci 40 2986-93

[8] Reuter S, Winter J, Schmidt-Bleker A, Tresp H, Hammer M U and Weltmann K-D 2012 Controlling the ambient air affected reactive species composition in the effluent of an argon plasma jet IEEE Trans. Plasma Sci 40 2788-94

[9] Barton A, Wende K, Bundscherer L, Weltmann K-D, Lindequist U and Masur K 2013 Non-thermal atmospheric pressure plasma treatment of human cells: the effect of ambient conditions Proc ISPC 21 (Cairns, Queensland, Australia)

[10] Tresp H, Hammer M U, Winter J, Weltmann K-D and Reuter S 2013 Quantitative detection of plasma-generated radicals in liquids by electron paramagnetic resonance spectroscopy J. Phys. D: Appl. Phys. 46435401

[11] Gaens W V and Bogaerts A 2013 Kinetic modelling for an atmospheric pressure argon plasma jet in humid air J. Phys. D: Appl. Phys. 46275201

[12] Gentile A C and Kushner M J 1995 Reaction chemistry and optimization of plasma remediation of $\mathrm{N}_{x} \mathrm{O}_{y}$ from gas streams J. Appl. Phys. 78 2074-85

[13] Liu D X, Bruggeman P, Iza F, Rong M Z and Kong M G 2010 Global model of low-temperature atmospheric-pressure $\mathrm{He}+\mathrm{H}_{2} \mathrm{O}$ plasmas Plasma Sources Sci. Technol. 19025018

[14] Murakami T, Niemi K, Gans T, O'Connell D and Graham W G 2013 Chemical kinetics and reactive species in atmospheric pressure helium-oxygen plasmas with humid-air impurities Plasma Sources Sci. Technol. 22015003

[15] Sakiyama Y, Graves D B, Chang H-W, Shimizu T and Morfill G E 2012 Plasma chemistry model of surface microdischarge in humid air and dynamics of reactive neutral species J. Phys. D: Appl. Phys. 45425201

[16] Babaeva N Y and Kushner M J 2013 Reactive fluxes delivered by dielectric barrier discharge filaments to slightly wounded skin J. Phys. D: Appl. Phys. 46025401

[17] Boeuf J-P, Yang L L and Pitchford L C 2013 Dynamics of a guided streamer ('plasma bullet') in a helium jet in air at atmospheric pressure J. Phys. D: Appl. Phys. 46015201

[18] Naidis G V 2011 Modelling of plasma bullet propagation along a helium jet in ambient air J. Phys. D: Appl. Phys. 44215203

[19] Sakiyama Y and Graves D B 2009 Neutral gas flow and ring-shaped emission profile in non-thermal RF-excited plasma needle discharge at atmospheric pressure Plasma Sources Sci. Technol. 18025022

[20] Zhang S, Gaens W v, Gessel B v, Hofmann S, Veldhuizen E v, Bogaerts A and Bruggeman P 2013 Spatially resolved ozone densities and gas temperatures in a time modulated RF driven atmospheric pressure plasma jet: an analysis of the production and destruction mechanisms J. Phys. D: Appl. Phys. 46205202

[21] Reuter S, Winter J, Schmidt-Bleker A, Schroeder D, Lange H, Knake N, Gathen V S-v d and Weltmann K-D 2012 Atomic oxygen in a cold argon plasma jet: TALIF spectroscopy in ambient air with modelling and measurements of ambient species diffusion Plasma Sources Sci. Technol. 21024005 
[22] Verreycken T, Mensink R, van der Horst R, Sadeghi N and Bruggeman P J 2013 Absolute $\mathrm{OH}$ density measurements in the effluent of a cold atmospheric-pressure $\mathrm{Ar}-\mathrm{H}_{2} \mathrm{O} \mathrm{RF}$ plasma jet in air Plasma Sources Sci Technol. 22055014

[23] Iséni $\mathrm{S}$, Reuter $\mathrm{S}$ and Weltmann K-D $2014 \mathrm{NO}_{2}$ dynamics of an Ar/Air plasma jet investigated by in situ quantum cascade laser spectroscopy at atmospheric pressure J. Phys. D: Appl. Phys. 47075203

[24] Reuter S, Winter J, Iseni S, Peters S, Schmidt-Bleker A, Dünnbier M, Schäfer J, Foest R and Weltmann K-D 2012 Detection of ozone in a $\mathrm{MHz}$ argon plasma bullet jet Plasma Sources Sci Technol. 21034015

[25] Winter J, Dünnbier M, Schmidt-Bleker A, Meshchanov A, Reuter S and Weltmann K 2012 Aspects of UV-absorption spectroscopy on ozone in effluents of plasma jets operated in air J. Phys. D: Appl. Phys. 45385201

[26] Dünnbier M, Schmidt-Bleker A, Winter J, Wolfram M, Hippler R, Weltmann K-D and Reuter S 2013 Ambient air particle transport into the effluent of a cold atmospheric-pressure argon plasma jet investigated by molecular beam mass spectrometry J. Phys. D: Appl. Phys. 46435203

[27] Weltmann K D, Kindel E, Brandenburg R, Meyer C, Bussiahn R, Wilke C and von Woedtke T 2009 Atmospheric pressure plasma jet for medical therapy: plasma parameters and risk estimation Contrib. Plasma Phys. 49 631-40

[28] Rothman L S et al 2005 The HITRAN 2004 molecular spectroscopic database J. Quant. Spectrosc. Radiat. 96 139-204

[29] neoplas control 2010 Q-MACSoft (IR simulation software)

[30] Winter J, Wende K, Masur K, Iseni S, Dunnbier M, Hammer M U, Tresp H, Weltmann K-D and Reuter S 2013 Feed gas humidity: a vital parameter affecting a cold atmospheric-pressure plasma jet and plasma-treated human skin cells J. Phys. D: Appl. Phys. $\mathbf{4 6} 295401$

[31] Novicki S and Krenos J 1988 Absolute quenching cross section for collisions between $\operatorname{Ar}(3 \mathrm{P} 0,2)$ and $\mathrm{H}_{2} \mathrm{O}$ J. Chem. Phys. 89 7031-3

[32] Sheldon J W and Muschlitz E Jr 1978 Quenching cross sections for $\operatorname{Ar}(\mathrm{P})$ and $\mathrm{Kr}(\mathrm{P})$ by $\mathrm{HO}$ and $\mathrm{DO}$ J. Chem. Phys. 685288

[33] Kutasi K, Guerra V and Sá P 2010 Theoretical insight into $\mathrm{Ar}-\mathrm{O}_{2}$ surface-wave microwave discharges J. Phys. D: Appl. Phys. 43175201

[34] Moravej M, Yang X, Barankin M, Penelon J, Babayan S and Hicks R 2006 Properties of an atmospheric pressure radio-frequency argon and nitrogen plasma Plasma Sources Sci. Technol. 15204

[35] Moravej M, Yang X, Hicks R F, Penelon J and Babayan S E 2006 A radio-frequency nonequilibrium atmospheric pressure plasma operating with argon and oxygen $J$. Appl. Phys. 99093305

[36] Yimer I, Campbell I and Jiang L-Y 2002 Estimation of the turbulent Schmidt number from experimental profiles of axial velocity and concentration for high-Reynolds-number jet flows Can. Aeronaut. Space J. 48 195-200
[37] AirLiquide 2014 http://www.airliquide.com/ en/alphagaz-specifications.html

[38] Gudmundsson J T and Thorsteinsson E G 2007 Oxygen discharges diluted with argon: dissociation processes Plasma Sources Sci Technol. 16399

[39] Waskoenig J, Niemi K, Knake N, Graham L M, Reuter S, Schulz-von der Gathen V and Gans T 2010 Diagnostic-based modeling on a micro-scale atmospheric-pressure plasma jet Pure Appl. Chem. 82 1209-22

[40] Winter J, Wende K, Masur K, Iseni S, Dünnbier M, Hammer M U, Tresp H, Weltmann K-D and Reuter S 2013 Feed gas humidity: a vital parameter affecting a cold atmospheric-pressure plasma jet and plasma-treated human skin cells J. Phys. D: Appl. Phys. 46295401

[41] Pipa A V, Reuter S, Foest R and Weltmann K-D 2012 Controlling the NO production of an atmospheric pressure plasma jet J. Phys. D: Appl. Phys. 45085201

[42] Dorai R and Kushner M J 2003 A model for plasma modification of polypropylene using atmospheric pressure discharges J. Phys. D: Appl. Phys. 36666

[43] DeMore W, Sander S, Golden D, Hampson R, Kurylo M, Howard C, Ravishankara A, Kolb C and Molina M 1997 JPL Publication 97-4 Jet Propulsion Laboratory 12

[44] Baulch D, Cobos C, Cox R, Frank P, Hayman G, Just T, Kerr J, Murrells T, Pilling M and Troe J 1994 Evaluated kinetic data for combustion modeling: supplement I J. Phys. Chem. Ref. Data 23847

[45] Atkinson R, Baulch D, Cox R, Crowley J, Hampson R, Hynes R, Jenkin M, Rossi M and Troe J 2004 Evaluated kinetic and photochemical data for atmospheric chemistry: Volume I-gas phase reactions of $\mathrm{O}_{x}, \mathrm{HO}_{x}, \mathrm{NO}_{x}$ and $\mathrm{SO}_{x}$ species Atmos. Chem. Phys. 4 1461-738

[46] Atkinson R, Baulch D, Cox R, Hampson R Jr, Kerr J, Rossi M and Troe J 1997 Evaluated kinetic and photochemical data for atmospheric chemistry suppl VI. IUPAC subcommittee on gas kinetic data evaluation for atmospheric chemistry J. Phys. Chem. Ref. Data 261329

[47] Atkinson R, Baulch D, Cox R, Hampson R Jr, Kerr J and Troe J 1992 Evaluated kinetic and photochemical data for atmospheric chemistry: Supplement IV. IUPAC subcommittee on gas kinetic data evaluation for atmospheric chemistry Atmos. Environ. A-Gen. 26 1187-230

[48] Baulch D, Cobos C, Cox R, Esser C, Frank P, Just T, Kerr J, Pilling M, Troe J and Walker R 1992 Evaluated kinetic data for combustion modelling J. Phys. Chem. Ref. Data 21 411-734

[49] Doroshenko V, Kudryavtsev N and Smetanin V 1992 Quenching mechanisms for electronically excited species in partially dissociated air High Energy Chem. 26227

[50] Gauthier M J and Snelling D R 1975 La photolyse de l'ozone a $253.7 \mathrm{~nm}$ : Desactivation de O (1D) et de O2 $\left({ }^{1} \Sigma\right)$ par les gaz de l'atmosphere J. Photochem. 4 27-50

[51] Dunlea E J and Ravishankara A 2004 Measurement of the rate coefficient for the reaction of $\mathrm{O}(1 \mathrm{D})$ with $\mathrm{H}_{2} \mathrm{O}$ and re-evaluation of the atmospheric $\mathrm{OH}$ production rate Phys. Chem. Chem. Phys. 6 3333-40 